\title{
Fictional and Non-fictional Narrative Representations of State Repression and Terror in the Dirty Wars in Argentina (1976-1983) and Chile (1973-1990)
}

\section{Ritwik Ghosh}

\begin{abstract}
I argue that fictional representations of the Dirty Wars in Argentina (19761983) and Chile (1973-1990) allow for the possibility of forgiveness and healing, while non-fictional representations such as testimonies and conversations do not. Focusing on a variety of fictional and non-fictional texts, I analyze why and how state repression inflicts trauma and violence upon its victims and survivors. The novels I analyze are no place for heroes by Laura Restrepo, El Angel's Last Conquest by Elvira Orphée and Bedside manners by Luisa Valenzuela. The nonfictional works I analyze are Nunca Mas: A Report By Argentina's National Commission on Disappeared People, That Inferno: Conversations of Five Women Survivors of an Argentine Torture Camp, Circle Over Death: Testimonies of the Mothers of the Plaza de Mayo and We, Chile: Personal Testimonies of the Chilean Arpilleristas. The theoretical underpinnings of my arguments are Paul Ricouer's Memory, History, Forgetting (2004) and Avishai Margalit's The Ethics of Memory (2002), both of which attempt to think through the relationship between forgetting and forgiving.
\end{abstract}

\section{Keywords}

Forgiveness, Dirty Wars, Argentina, Chile, Ricouer, Avishai. 



\title{
Fictional and non-fictional narrative representations of state repression and terror in the Dirty Wars in Argentina (1976-1983) and Chile (1973-1990)
}

\author{
Ritwik Ghosh
}

\section{Introduction}

The fictional representations of the Dirty Wars in Argentina (1976-1983) and Chile (1973-1990) make forgiveness and healing possible and thinkable, while the nonfictional representations largely do not. The "Dirty Wars" in Latin American countries such as Argentina (1976-1983) and Chile (1973-1990) saw military regimes which abducted, tortured, murdered, and disappeared (desaparecido) thousands of their political opponents in the name of anticommunism, and thousands were driven into exile (Kohut and Vilella 1). Military ideology in Latin America reacted to a threat, not from an external invading enemy, but from suspected "subversives" within its national borders (Kohut and Vilella 1). According to M.L.R Smith and Sophie Roberts a "Dirty war" is a "systematic campaign of violence directed against a portion of the civilian populace where the perpetrators aim to conceal both the extent of the violence and the true extent of their involvement for the primary purpose of creating fear for political purposes" (Kohut and Vilella 2).

The "Dirty Wars" waged by Latin American countries, were aimed primarily at the left and those perceived to be its supporters, with guerilla movements and left-wing political parties suffering heavy losses (Kohut and Vilella 3). Anyone whose ideas were perceived to be antithetical to government notions of "Western, Christian civilization" could be labeled subversive including journalists, labor activists, schoolteachers, university professors, progressive church leaders and high school students (Kohut and Vilella 3). Suspected subversives were abducted, taken to secret prisons, tortured, and often killed or exiled (Kohut and Vilella 3).

Groups and individuals, at great risk to themselves spoke out (Kohut and Vilella 3). Local human-rights groups emerged, including the Mothers of the Plaza de Mayo and the Grandmothers of the Plaza de Mayo in Argentina, and the Vicariate of Solidarity in 
Chile (Kohut and Vilella 3). Acts of cultural resistance were expressions of non-violent protest and solidarity (Kohut and Vilella 143). Chief examples were literary works and films (Kohut and Vilella 3).

The theoretical framework of my argument about forgiveness is by Paul Ricouer in his last work Memory, History, Forgetting (2004) and Avishai Margalit in The Ethics of Memory (2002). For Ricouer, central to the ethics of memory is the relation between forgetting and forgiving (Rossington and Whitehead 12). Ricouer makes a distinction between forgetting in reserve, where a memory of the injury can still be called to mind, and total forgetting (Rossington and Whitehead 12). Margalit states that Ricouer is likely to prefer forgiving with forgetting in reserve rather than with total forgetfulness (Rossington and Whitehead 12).

Margalit, like Ricouer, considers the relation between forgiving and forgetting (Rossington and Whitehead 12). Margalit, like Ricouer, distinguishes between two types of forgiveness: forgiveness as blotting out the sin and forgiveness as covering it up (Rossington and Whitehead 12). Margalit decisively states that forgiveness is based on disregarding the sin rather than forgetting it (Rossington and Whitehead 12). The relationship between forgetting and forgiving is important in confronting the problem of how to live with and move on from traumatic histories (Rossington and Whitehead 13).

Laura Restrepo's novel Demasiados héroes originally published in Spain in 2009, and translated into English by Ernesto Mestre-Reed as no place for heroes develops the thematic material of the Argentine dirty war (1976-1983) by investigating the familial conflicts and longings of a family where a son searches for a long lost father. The historical setting of Restrepo's no place for heroes is the dirty war in Argentina, which genocide scholar Adam Jones notes, is in Argentina widely considered as a genocide with the term being considered vitally valid, to recognizing the victims' pain and trauma (Jones 673, 692-693). M. Edurne Portela states that the seven years of military rule called the "Processo" or "Dirty War" (1976-1983) resulted in about 30,000 deaths and disappearances (desaparecidos).

A military coup took place on March 24, 1976, headed by General Jorge Rafael Videla, Admiral Emilio Massera, and General R. Agosti, each representing one branch of the military, with an ambitious plan named the "Proceso de Reorganización Nacional" (Process of National Reorganization) which through violence attempted to restructure the economy, labor relations, education, and international relations, forbade all political parties, shut down parliament, restructured the judiciary, forbade freedom of speech and censored all media, and eliminated all political, economic, and religious dissidents from positions of power and replaced them with their supporters (Portela 13). According to the Junta, the Proceso had as the main goal to restore "Western, Christian civilization" and to eliminate "subversion" from Argentina, which was the scenario for "World War III" between East (Communism) and West (Christian civilization) (Portela 13). The term "subversive" referred not only to the armed guerillas but to any Argentine who could be suspected of disagreement with the military regime (Portela 13). 
The desaparecidos, those who were "disappeared" by the state authorities were tortured to death or executed. Pregnant detainees were often allowed to give birth before being killed, with the infants then turned over to be adopted by military families (Jones 673). Jared Diamond, who considers the Argentine dirty war as genocide, states that this behavior by Argentine soldiers is unique (Diamond 294). In 1982 following the Argentine defeat by Britain in the war over the Falkland Islands military rule came to its decline (Jones 673). In 1983 free elections were held, and Raúl Alfonsín of the Radical Civic Union (UCR) was sworn in as President in December (Jones 673). That month also saw the creation of the National Commission on Disappeared People/Comisión Nacional Sobre La Desaparición De Personas (CONADEP), which investigated the fate of those who disappeared (desaparecidos) under the military regime (Jones 673). Its report came out in 1984 under the title Nunca Más (Never Again) (Jones 673). The report cataloged 8,960 'disappearances' and listed 340 clandestine abduction centers in Argentina (Jones 673). The most notorious of the state detention facilities was the Naval Mechanics School (Escuela Mecánica de la Armada, ESMA) in the Palermo Suburb of Buenos Aires (Jones 673). In 2004 the government of Nestor Kirchner, expropriated the site and declared it would house a "Museum of Memory," to educate current and future generations about the period of state terror (Jones 673).

By March 2016, more than 600 people had been convicted for dirty war crimes committed during the past 10 years (Kohut and Vilella 47). In addition to overseeing trials, Fernández de Kirchner oversaw the completion in 2010, of the Museum of Memory, which had opened in April 2008, on the site formerly occupied by ESMA (Kohut and Vilella 47).

Laura Restrepo is a Colombian novelist, essayist, and journalist, who has taught at the National University in Bogotá, Colombia, and has been the director of the important news weekly Semana (Williams 303). She has lived in Colombia, Spain, and Mexico (Williams 303). Since the 1990s she has been one of Colombia's most widely read and commercially successful women writers and is best associated with commercial fiction and the post-Boom (Williams 303).

Restrepo was trained as a journalist and was initially known in Colombia for her journalistic writing (Williams 47). She began publishing fiction in the 1980's and has grown to be a bestselling novelist in the Andean region in the 1990's (Williams 47).

It was in the 1960's in the Boom that the Latin American novel changed and caught up with the poetry of Latin America (González Echevarría 83). The Boom writers incorporated modernist narrative techniques (González Echevarría 83). In the 1980 's a deliberately post-Boom literary movement appeared that attempted to distance itself from the Boom and its magical realism and modernist aesthetics (González Echevarría 115). The newer writers of the post-Boom portrayed Latin America as urban, globalized, and they often wrote in a realist style (González Echevarría 116). These postBoom writers were perhaps more interested in individual rather than cultural identity (González Echevarría 116). Two developments between the 1970's and 1990's are the emergence of the testimonio and the New Historical Novel (Kristal 92). Testimonio or 
testimonial writing is a kind of autobiography told by another person (Kristal 92). Testimonio gives voice to marginalized and victimized people (Kristal 92). The New Historical Novel, a notion posited by critic Seymour Menton in 1993, often revisits the history of the colonial and Independence periods (Kristal 92). It was between 1960 and 1970 in the European and North American publishing world that the Latin American novel was discovered, translated and lauded by a new public (Kristal 305).

Aníbal González states that the relationship between literature and journalism is an important element in the literary history of Spanish America (González 2). González argues that the link between literature and journalism is a means for Spanish American writers to attain the modernity they see in Europe and the United States (González 14). The link between literature and journalism in Spanish America underlines the region's bond with its western cultural heritage, according to González (González 14). The first work of narrative prose in Spanish America to openly proclaim itself a work of fiction and to associate itself with the novel genre is El Periquillo Sarniento (1816) by the Mexican pamphleteer José Joaquín Fernández de Lizardi (González 21). Gabriel García Márquez, Mario Vargas Llosa and Elena Poniatowska are Spanish American writers who have practiced journalism and have visibly incorporated it into their novels (González 111). Lois Parkinson Zamora states that Latin American fiction is characterized by an anxiety of origins (Zamora 5).

By the end of the 1980's testimonial narrative began to be displaced by a variety of sentimental and amorous narratives whose popularity grew as Spanish America was undergoing a process of democratization and globalization (González 3).

Roberto González Echevarría states that the novel establishes with the discourse of the law a productive and determining relationship (González Echevarría ix). González Echevarría states that at the beginning of writing, at its origin, is the language of the law (González Echevarría). For González Echevarría the figure of the archive as myth constitutes the core of much Latin American fiction (González Echevarría 4).

In Laura Restrepo's novel no place for heroes we are introduced to the characters Lorenza and Ramón who are two militants opposing Videla's regime who met and fell in love. At the commencement of the novel Lorenza and her son by Ramón, named Mateo are planning to come to Buenos Aires to find Ramón. For Lorenza coming back to Argentina revives her past life, full of passionate conviction, political ideology and past friendships and acquaintances. For Mateo, the search is for a long-lost father, who is longed for and imagined. The relationship between mother and son is volatile but friendly. The relationship between mother and father is estranged and contentious. The novel reveals that militancy is an intensely difficult undertaking, requiring the conflation and reorientation of private lives and worlds.

In Restrepo's novel no place for heroes it is Lorenza who heals by asserting her agency and recovering her child Mateo, and Mateo forgives and heals himself by reintegrating his life with that of his father. Familial meeting and reintegration, as well as a feminist agency are the sources of forgiveness and healing in Restrepo's novel. 
Argentine author Elvira Orphée's 1983 novel La Ultima Conquista De El Angel translated into English by Magda Bogin as El Angel's Last Conquest is an aesthetically successful artifact. The novel explores the theme of torture in the Argentine dirty war (1976-1983). The cover design and book design add to the harrowing effect of reading the novel.

The novel opens with a torturer's perspective. The writing combines the sublime and the horrific, the mundane and the dreadful. In the chapter entitled "Ceremony" the unnamed narrator who is an apprentice torturer admirers his superior Officer Winkel who states regarding the task of torture- "In perfecting the world's finest, anything goesgreen light to the imagination, be creative (Orphée1). The narrator admires Officer Winkel for his efficiency and agility. Winkel is admired for the martial, fascist aura he exudes- "An aura of will, of duty, of triumph foreshadowed and foreknown-something like that had scrubbed him cleaner than soap or water ever could"(Orphée 2). Winkel emphasizes the need to instill fear within the victims.

Elvira Orphée's El Angel's Last Conquest is a study in the dark atmosphere of torture told from the perspective of the torturers. The chiaroscuro of the writing is always shrouded in darkness. Orphée's writing is not polite, it does not seek to soothe, charm or beguile. Mercilessly the writing seeks to discomposure and discomfort the reader by rearranging the sense of reality and lived experience. The writing seeks to unsettle the reader into surprise and wonder. The writing is not merely imitative of the world of torture, it seeks to create a reality of its very own. The writing seeks not to create beauty but the disruption of our sense of the mundane, everyday and the banal. Orphée is interested in a dramatized form of prose writing, that seeks to shock the reader and offers a vivid sense of reality. Visually dark, the world she conjures is claustrophobic. Throughout the novel Orphée seeks to disorient the reader psychologically and offers a parallel, alternate world where things have gone awry. The world of the torturers is skeletal, metallic and mechanical; it does not offer soothing visions or uplifting moments. Orphée seeks to defy convention, challenge complacency and shift our awareness in her depiction of the world from the viewpoint of the torturer. The austerely dark imagery that the writer employs is designed to cloak the reader in an uncompromising feeling of the sordid. The reader is invited into a world saturated with death. The writing discovers many ways of folding death into life and absences into presence. We are given an atemporality of narration, a desiccation of pain, and a remoteness of stance designed to invoke the horror of torture and trauma. The lightness and austerity of construction marks the writing making it precise and pointed. In its intensity and intuition of the dark complexities and tragic force of torture, Orphée's writing is an otherworldly experience for the reader. The refusal to openly grieve heightens the tragic power of the writing. The construction of memory in Orphée's writing is bleak and without hope. In the invention of memory Orphée's writing has an impacted density that makes it both fugal and memorable. Forgiveness and healing, it seems is a fragile possibility, but that which is premised on gaining a full understanding of the perpetrator and of the extent of criminal possibility. Rather than shying away from 
understanding wrongdoing, Orphée wants us to fully understand the perpetrator and the full possibilities of criminal behavior. By gaining a full psychological profile of the perpetrator we are better able to forgive and therefore to heal ourselves. By immersing us in the world of the torturer, Orphée makes us understand the thought processes by which torture is justified and perpetrated. By showing us the full experience of sorrow, Orphée's text, paradoxically, begins to show us the uncanny sensation of the end of sorrow. Orphée's text is not a lamentation, nor longing, but gives us the afterlife of torture for survivors. The novel ends not in gentle resignation but in catastrophic intensity. The vertigo of a betrayed epistemic security is imparted to the reader in the course of reading the novel. Orphée allows us to transform experiential loss into imaginative gain by giving us insight into perpetrators and their criminality, so that we may understand what we may oppose, and by understanding gain healing and forgiveness.

Luisa Valenzuela's 1990 novel Realidad nacional desde la cama translated by Margaret Jull Costa as Bedside Manners concerns the return of a woman from exile, back to Argentina after the restoration of democracy and the end of the dirty war in Argentina (1976-1983).In the novel a woman returns to her country, Argentina, after a long absence and finds it hard to fit in. She goes to a bungalow in a country club in search of rest. The country club is occupied by military men planning a coup. The rebel army attempts to overthrow the government but fails to do so, partly because a doctor disguised as a colonel tells the troops to lay down their weapons and dismiss themselves. Instead of completing the coup, the soldiers, who are starving, focus on eating food. The doctor named Alfredi rescues the situation, and is the lover of the woman. The woman and Alfredi dance together in their victorious success at ending the coup. The novel uses a great deal of magical realism, as the bed becomes the site for soldiers to arrive and disappear. The novel praises de-escalation, demilitarization and arms control. Music and dance are central to the celebrations that end the novel. Memory is contested in the novel -"I came back to recover my memory and they steal it from me, erase it. They sweep it away." Exile and return allow for an intensification of the contest over the meaning of memory. Forgiveness and healing in the novel is achieved through the sharing of food, music and dance.

Luisa Valenzuela is an Argentine novelist, short story writer, and essayist and is considered a major contemporary woman writer in Latin America (Leslie Williams 337). She is an urban writer with interests in politics and feminism (Leslie Williams 337). Valenzuela was born in Buenos Aires in 1938 and reared in a family of intellectuals (Leslie Williams 337).

The three fictional texts I have analyzed all allow through imaginative possibilities the attainment of some measure of healing and forgiveness. I argue that the non-fictional texts on the dirty wars largely do not allow for the possibility of healing and forgiveness, as memory in them is too full and too abundant to allow room for forgiveness. 
Nunca Más, which is the report of Argentina's National Commission on Disappeared People, was set up by President Raúl Alfonsín after he took office in 1983. The report states that at least 8,960 people were disappeared (desaparecido) (Nunca Más 10). 62 percent were detained in their own homes (Nunca Más 11). Alberto Santiago Burnichon's disappearance and death are described by his wife, who states that her husband's body was found with seven bullet wounds in the throat (Nuna Más 12). The gangs that carried out the abductions, did not bother to conceal their faces (Nunca Más 13). Adolfo T. Ocampo describes how his daughter was abducted and states that the gang shouted "We've been given a free zone" (Nunca Más 14).

If the assailants did not find their intended victim at home, they prepared a 'mousetrap', and stayed until the person they sought returned (Nunca Más 15). If the originally intended victim did not appear, the attackers often took away someone else such as a relative (Nunca Más 15). The father of the Barroca family states that his daughter was abducted for being a member of the Peronist University Youth (Nunca Más 15).

The robberies carried out by the assailants in the homes of those abducted were considered by the forces involved as 'war booty' (Nunca Más 16). Jorge Eduardo Alday's wife in her testimony states that the assailants looted all their goods and belongings and piled them onto trucks (Nunca Más 17). Rita Verónica Eroles Turucz states in her testimony that the assailants stole many things such as books and electrical goods (Nunca Más 18).

Carlos Alberto Campero's testimony states that his mother was tortured in their own home (Nunca Más 18). Mirta Caravelli de Mansilla states that the assailants blindfolded, gagged and handcuffed her and wrapped a pullover around her head (Nunca Más 19). Marcelo Daniel Vilchez states that the assailants put a pullover over his eyes and later put a blindfold over his eyes (Nunca Más 19). Dr Norberto Liwsky in his testimony describes the extensive torture he was subjected to, which included electric shocks for days, and systematic beatings (Nunca Más 22). The torture suffered by Dr Liwsky was sadistic and extensive.

While forgiveness and healing are possibilities in the novelistic representations of the dirty wars, the testimonies in Nunca Más appear to have no space for forgiveness and little for healing. That Inferno: Conversations of Five Women Survivors of an Argentine Torture Camp contains testimonial conversations by five women who survived torture in the 1970's in the Mechanics School of the Argentine Navy. The period from 1976 to 1983 in Argentina is known as the dirty war, which saw the torture and murder of at least 8,960 people, though human rights groups place the actual figure at 30,000 (Kohut and Vilella 35). When the coup took place on March 24, 1976, Argentina's economy had collapsed and violence was widespread (Portela 12). The military headed by General Jorge Rafael Videla, Admiral Emilio Massera, and General Orlando R. Agosti, each representing one arm of the military, was ready to take the power of government and systematize state repression (Portela 12). The regime was headed by a succession of four juntas (Feitlowitz 8). The most brutal years were 1976 to 1979 (Feitlowitz 8). 
The testimonial conversations in That Inferno were recorded in taped discussions over three and a half years (Actis 22). The five women would meet in a terrace room that had windows through which to see the sky (Actis 23). The women had gone through unique experiences (Actis 23). The group used humour to ward off anguish (Actis 23). The women created a climate of affection and tolerance to make the conversations possible (Actis 24). These conversations are part of the collective memory of the dirty wars (Actis 25).

Some militants chose to commit suicide at the moment of capture to prevent turning in their fellow militants under torture (Actis 27). Munú and Liliana agree that their type of militancy required them to engage in a pretense with others that helped them resist inside the Navy Mechanics School known as ESMA (Actis 27). Liliana states that they had already experienced living a clandestine life by hiding their militancy from others (Actis 27). Miriam states that she was caught as she used a public telephone (Actis 30). Miriam states that there were times when she didn't have any place to sleep (Actis 33). Adriana states that they had to sound consistent with the fictitious person they were pretending to be (Actis 33). Miriam states that militants ended up completely alone, as they were shunned by a fearful society, afraid of the stories of repression going around (Actis 34).

Elisa states that her loneliness was so extreme that she sank into a depression (Actis 34). Miriam states that sometimes they would have to sleep in a hotel (Actis 35). Miriam states that in general they had very little clothing (Actis 36). Cristina states that they had to take temporary jobs (Actis 37). Miriam states that the daily deaths affected her (Actis 37). Liliana states that they formed very intense relationships and their conversations were very intense (Actis 37). Elisa states that sometimes she would go to the theater or to the movies (Actis 37). Miriam states that they were relating to people who had suffered huge losses (Actis 38). Cristina states that at varying levels of consciousness all of society lived in fear (Actis 38). Miriam states that they considered suicide with the pill (Actis 39). Miriam states that the leaders had a glass pill that cut the tongue allowing the cyanide to enter the bloodstream right away (Actis 40). Miriam states that they bought cyanide from a laboratory (Actis 40). Munú states that they were involved in a kind of militancy in which the society was more important than the individual (Actis 41). Munú states that the oppressors at the ESMA once took her out to dinner (Actis 42). Elisa states that it was only after therapy that she began to understand that the marinos had destroyed a part of her (Actis 43). Liliana states that during her first few days in the ESMA she had fantasies of killing herself (Actis 43). Cristina states that she had gone through the loss of her husband and the experience of torture (Actis 44). Cristina attempted to electrocute herself in a suicide attempt (Actis 44). Elisa states that it drove the oppressors crazy that someone would choose her own death (Actis 47). Miriam states that sometimes the oppressors used a regular siphon to pump the stomach (Actis 47). Gabi or Norma Arrostito was killed by an injection according to Elisa (Actis 48). Elisa states that working as a typist gave her a chance to survive (Actis 48). 
Miriam states that there was no guarantee of survival in the ESMA, and being selected to work was no guarantee (Actis 51). Miriam states that the marinos liked it when they dressed well as it was a sign of recuperation (Actis 52). The harrowing testimonial conversations in That Inferno are full of traumatic memories and have little to no space for healing or forgiveness.

Matilde Mellibovsky's edited collection of testimonies Circle of Love Over Death: Testimonies of the Mothers of the Plaza de Mayo memorializes the experiences of survivors and victims of Argentina's dirty war (1976-1983). The book attempts to preserve the memory of those who were tortured, disappeared (desaparecidos) and killed by the Argentine military regime. Poema Gardella De Akerman's testimony of the abduction and killing of her daughter Leticia Mabel Akerman, vividly depicts the life and personality of Leticia. It gives us a sense of the intellectual background of Leticia and her sense of purpose. Leticia was a participant in the High School Students' Union.

Lola Weinschelbaum De Rubino's testimony of her daughter Raquel Del Carmen Rubino Weinschelbaum, who was abducted at the age of 21 gives a sense of her life and background. It paints a picture of her struggles against poverty and her commitment to social justice. She was a participant, a high school teacher, in a Union meeting called by the teachers of San Isidro's primary school at school \#1.

Maria Adela Gard De Antokoletz's testimony of her son Daniel Victor Antokoletz, who was abducted is revelatory. He was a lawyer who defended political prisoners in Argentina and Chile, he wrote a report to the Third congress of the Argentine Association of International Law on the increase of violations of the right to asylum, and he repeatedly denounced the harsh conditions of the prisons and of the general lack of respect for human rights in Argentina. He kept on defending political prisoners after the March 1976 military coup. This testimony also states that a spy priest named Emilio Grasselli got information out of the Mothers.

Lidia Miy Uranga De Almeida's testimony of her son Alejandro Martin Almeida, reveals that he was and remains a gifted poet. He was against the military, while she had been in favour of the armed forces before his abduction. Elida Busi De Galletti, mother of Liliana Galletti, relates how her family was destroyed by the loss of her daughter. At the end of 1976 Liliana had gone to the Permanent Assembly for Human Rights and was writing reports for a group of people that were to form the Argentine Commission on Human Rights.

Esther Aracela Lado De Sanchez, mother of Enrique Sanchez, states that her son has been unjustly jailed before his disappearance. Her testimony claims that it was in 1974 that kids started to disappear. She stated that she had gone to the Argentinian League for Human Rights.

Carmen Robles De Zurita, was the mother of Nestor Juan Agustin Zurita, and Maria Rosa Zurita, both of whom were disappeared (desaparecidos). Her daughter was taken ninety days after her son. Her son was taken with another kid whose name is Roberto. Her testimony claims that the Church was in complicity with the military. Her lawyer was also murdered. 
Fanny Brener De Bendersky, the mother of Daniel Bendersky, who was abducted when he was 26 years old states that Daniel had with a group of fellow students collected money to help the Mothers of the Plaza in their fight. Enriqueta Maroni, mother of Juan Patricio Maroni and Maria Beatriz Maroni De Rincon and mother-in-law of Carlos Alberto Rincon states that on April 5, 1977 her house and that of her daughter was raided. She lost her son, her daughter and her daughter's husband. They participated in Catholic young people's movements and nurtured their Christian and social ideals. The tragedy took away the most profound religious convictions of Enriqueta Maroni.

Marta Vazquez, mother of Maria Marta Vazquez De Lugones, who was abducted with her husband Cesar Amadeo Lugones states that her daughter and her husband worked in the little school in Belen. Maria Marta and Cesar were militants and they were friends with several priests. She states that the forces of repression also caused the disappearance of Azucena and the French nuns. Angelica P. Sosa De Mignone, mother of Monica Maria Calanderia Mignone, who was abducted at 24 years of age states that her daughter undertook missionary work at the Bajo Flores shantytown. Monica wrote an essay which is included in the book From the Silence where she stated that the law only protects the rich.

Josefina Gandolfi De Salgado, mother of Jose Maria Salgado who was abducted and murdered stated that the Armed Forces Command put out a story concerning his death in a confrontation with security forces near 400 Canalejas Street. She states that her son was sadistically destroyed alive and was hard to recognize. His eyes were missing and teeth destroyed. She states that the alleged confrontation was spurious. His hands and arms were covered with circular brownish spots, burned scars left by electric shock. She stated that she found out that Jose Maria was held in detention clandestinely at ESMA. He was tortured by Navy boys and murdered by an illustrious police chief at the internal security branch of the Federal Police.

Carmen Aguiar De Lapaco, mother of Alejandra Monica Lapaco, who was abducted at the age of 19 states that when she started college her militancy in the Peronist Youth movement began. Her daughter and her daughter's boyfriend remain disappeared. Her testimony also reveals that her family was the victim of anti-Semitism.

Carmen Isabel Rodino De Cobo, mother of Ines Adriana Cobo, who was abducted at the age of 22 states that the abduction happened on the street. Her younger daughter Neomi was also abducted on two occasions but was released without explanation. Ines's boyfriend Ruben Alberto Stockdale was abducted on September 3, 1977 after refusing to leave Argentina so as to search for her.

The testimonies construct a collective memory of trauma and remembrance that embodies and transcends its historical period. They evoke a long afterlife of loss that is haunting and harrowing. The testimonies vividly bring the victims to life as people with families and personalities. The testimonies show transmission of loss across intergenerational memory. There is little space for forgiveness and healing in these testimonies. 
The dirty war in Chile (1973-1990) started on $11^{\text {th }}$ September 1973, when the Chilean military overthrew Salvador Allende, a democratically elected Marxist President (Kohut and Vilella 118). The coup was led by Augusto Pinochet Ugarte and unleashed a reign of terror on the civilian population (Kohut and Vilella 118). Pinochet Ugarte began a series of campaigns against leftists and other perceived subversives (Kohut and Vilella 118). The two main sports arenas in Santiago became detention centers and thousands of political prisoners were arrested and subjected to torture with many killed (Kohut and Vilella 118).

On $24^{\text {th }}$ April 1990, one month after taking office, President Patricio Aylwin Azócar established the National Commission on Truth and Reconciliation, which documented deaths and disappearances committed during the dictatorship (Kohut and Vilella 123). The commission issued its report in 1991 and documented almost 3,200 cases of human-rights abuse involving death, with more than 1,000 of them missing (Kohut and Vilella 123).

We, Chile: Personal Testimonies of the Chilean Arpilleristas, edited by Emma Sepúlveda contains the testimonies of arpillera weavers. Arpilleras are woven tapestries depicting scenes of daily life. The Arpilleristas, as the women weavers came to be known, became powerful voices of dissent to the rule of Augusto Pinochet Ugarte. They depicted the desaparecidos (missing), the repression, the food and housing shortages caused by the regime's economic policies and the realities of life under the dictatorship (Kohut and Vilella 48).

Violeta Morales, sister of Newton Morales, who was arrested and disappeared on August 13, 1974, states that Newton Morales was elected by his fellow workers to the post of president of the union at the Sumar polyester plant (Sepúlveda 41) After the September 11, 1973 military coup the junta came out with a decree ordering everyone who was a union leader to report to work (Sepúlveda 41). Newton Morales was abducted at his mother's house (Sepúlveda 43).

Gala Torres Aravena, sister of Ruperto Torres Aravena, who was arrested and disappeared in October 1973, states that her brother was detained at the police station, after which he disappeared (Sepúlveda 83). She does not know what happened to her brother. She does not know whether he is in prison or whether he is alive or dead (Sepúlveda 86).The testimonies of the arpilleristas have little to no space for forgiveness and healing, and they are full of grief and sorrow.

While the three novels I have analyzed make forgiveness and healing possible, by giving imaginative possibilities for forgiveness, the four non-fictional testimonial works do not have much space for forgiveness and healing, as memory in them is too immediate and full. In Laura Restrepo's no place for heroes familial meeting and reintegration, as well as a feminist agency are the sources of forgiveness and healing. In Elvira Orphée's El Angel's Last Conquest the attainment of forgiveness is premised on gaining a full understanding of the perpetrator and of the extent of criminal possibility. In Luisa Valenzuela's Bedside Manners forgiveness and healing is achieved through the sharing of food, music and dance. The reasons why fiction can make forgiveness 
possible and thinkable are the imaginative possibilities of fiction and because fiction carries within it a measure of forgetting.

\section{Works Cited}

Actis, Munú, et al. That Inferno: Conversations of Five Women Survivors of an Argentine Torture Camp. Translated by Gretta Seibentritt. Vanderbilt University Press (TN), 2006.

Mellibovsky, Matilde. Circle of love over death: Testimonies of the Mothers of the Plaza de Mayo. Curbstone Press, 1997.

Orphee, Elvira. El Angel's Last Conquest. Ballantine Books, 1985.

Restrepo, Laura. No place for heroes: a novel. Doubleday, 2010.

Sabato, Ernesto, editor. Nunca Mas: A Report By Argentina's National Commission On Disappeared People. Faber and Faber, 1986.

Sepulveda, Emma, editor. We Chile: Personal Testimonies of the Chilean Arpilleristas. Azul Editions, 1996.

Valenzuela, Luisa. Bedside Manners. High Risk Books, 1990.

Dávila, Jerry. Dictatorships in South America. Wiley-Blackwell, 2013.

Diamond, Jared. The Third Chimpanzee: The Evolution And Future Of The Human Animal. Harper Perennial, 1992.

Feitlowitz, Marguerite. A lexicon of terror: argentina and the legacies of torture. Oxford University Press, 1998.

Finchelstein, Federico. The ideological Origins of the Dirty War: Fascism, Populism, and Dictatorship in Twentieth Century Argentina. Oxford University Press, 2014.

González Echevarría, Roberto. Modern Latin American Literature: A Very Short Introduction. Oxford University Press, 2012.

González, Aníbal. Journalism and the development of Spanish American narrative. Cambridge University Press, 1993.

González, Aníbal. Love and Politics in the Contemporary Spanish American Novel. University of Texas Press, 2010.

Guest, Iain. Behind The Disappearances: Argentina's Dirty War Against Human Rights And The United Nations. University of Pennsylvania Press, 1990.

Jones, Adam. Genocide: A Comprehensive Introduction: Third Edition. Routledge, 2017.

Kohut, David and Olga Vilella, ed. Historical dictionary of the dirty wars: Third Edition. Rowman \& Littlefield, 2017.

Lewis. Paul H. Guerillas and Generals: The "Dirty War" in Argentina. Praeger, 2002.

Margalit, Avishai. The Ethics of Memory. Harvard University Press, 2002.

Meierhenrich, Jens. Genocide: A reader. Oxford University Press, 2014.

Menton, Seymour. Latin America's New Historical Novel. The University of Texas Press, 1993.

Portela, M. Edurne. Displaced Memories: The Poetics of Trauma in Argentine Women's Writing. Bucknell University Press, 2011.

Ricoeur, Paul. Memory, History, Forgetting. University of Chicago Press, 2004. 
Rossington, Michael and Anne Whitehead. Theories of Memory: A Reader. John Hopkins University Press, 2007.

Schmidli, William Michael. The Fate Of Freedom Elsewhere: Human Rights and U.S. Cold War Policy Toward Argentina. Cornell University Press, 2013.

Williams, Raymond Leslie. The Columbia Guide to the Latin American Novel Since 1945. Columbia University Press, 2007.

Zamora, Lois Parkinson. The Usable Past: The Imagination of History in Recent Fiction of the Americas. Cambridge University Press, 1997.

\section{The Author}

\section{Ritwik Ghosh}

St. Xavier's University, India

E-mail: ritwik.ghosh1@gmail.com

\section{The Article}

Date sent: 27/04/2021

Date revised: 15/06/2021

Date Accepted: 18/06/2021 